\title{
Intramolecular Single-Turnover Reaction in a Cytochrome $c$ Oxidase Model bearing a Tyr244 Mimic
}

\author{
James P Collman ${ }^{*}$, Richard A Decréau, Yilong Yan, Jungjoo Yoon, and Edward I. Solomon \\ Department of Chemistry, Stanford University, Stanford, California 94305-5080
}

In the terminal step of respiration, cytochrome $\mathrm{c}$ oxidase $(\mathrm{CcO})$ carries out the $4 \mathrm{e}$ - reduction of dioxygen to water. ${ }^{1}$ This reaction is coupled to the ATP synthesis, the main energy storage source in the body. In healthy organisms $\mathrm{CcO}$ performs without releasing toxic partially reduced oxygen species. ${ }^{1}$ Three electrons involved in the reduction originate from the $\mathrm{Fe}^{\mathrm{II}} a_{3} /$ $\mathrm{Cu}^{\mathrm{I}}$ active site. The fourth electron and a proton come either from a tyrosine-244 (mixed valence enzyme) or from $\mathrm{FeA} / \mathrm{CuA}$ (fully reduced enzyme, with proton translocation across the membrane) leading to an oxoferryl-cupric-tyrosyl radical intermediate $\left(\mathrm{P}_{\mathrm{M}}\right)$ or oxoferrylcupric intermediate $\left(\mathrm{P}_{\mathrm{R}}\right)$, respectively. ${ }^{2 \mathrm{a}-\mathrm{f}}$ We previously reported a stable $\mathrm{Fe}^{\mathrm{III}}$-superoxide$\mathrm{Cu}^{\mathrm{I}} \mathrm{C} c \mathrm{O}$ model ${ }^{3 \mathrm{a}}$ that reacts intermolecularly with exogeneous Tyr244 mimics leading to phenoxyl radicals and an oxoferryl-cupric species, mimicking the $\mathrm{P}_{\mathrm{M}}$ intermediate. $3 \mathrm{~b}$ Based on the crystal structure of the enzyme, ${ }^{4 a b}$ we have constructed an $\mathrm{Fe}^{\mathrm{II}} \mathrm{Cu}^{\mathrm{I}} \mathrm{CcO}$ model 1 (Figure 1) that faithfully reproduces the structural heme $a_{3}-\mathrm{Cu}_{\mathrm{B}}$ motif with a built-in histidine-tyrosine cross link. ${ }^{5 \mathrm{a}-\mathrm{c}}$ The present study is designed to explore the validity of the mixed-valence scenario by showing that $\mathbf{1}$ having all the three redox centers present in the enzyme active site, can first react with $\mathrm{O}_{2}$ to form $\boldsymbol{o x y}-\mathbf{1}$ that subsequently reacts intramolecularly to give spectroscopic features that are associated with the $\mathbf{P}_{\mathbf{M}}$ intermediate (species $\mathbf{2}$, Scheme 1).

Oxygenation of $\mathbf{1}$ at $-60 \mathrm{C}^{\circ}$ leads to $o x y-\mathbf{1}$, a stable species that has the features of a Fe $\mathrm{Fe}^{\mathrm{III}}$ superoxide-Cu ${ }^{\mathrm{I}} .3 \mathrm{~b}, 7 \mathrm{a}-\mathrm{c}$ This intermediate is EPR silent, and resonance Raman spectroscopy showed an oxygen isotope sensitive band at $575 / 549 \mathrm{~cm}^{-1}\left({ }^{16} \mathrm{O}_{2} /{ }^{18} \mathrm{O}_{2}\right)$ characteristic of a hemesuperoxide $(O x y)$ species (Figure $2 \mathrm{~A}) .{ }^{3 \mathrm{~b}, 7 \mathrm{a}-\mathrm{c}}$ Moreover slight modification of the UV/Vis spectrum is noticed upon formation of oxy-1.

Upon warming to $-40 \mathrm{C}^{\circ}$, the $\mathrm{Fe}-\mathrm{O}_{2}$ stretching mode decays while intermediate species oxy-1 undergoes a subsequent intramolecular redox process similar to that which is thought to take place in $\mathrm{CcO}$. In this process leading to species 2 (scheme 1), the distal $\mathrm{Cu}^{\mathrm{I}}$ group becomes oxidized to an aquo or hydroxo $\mathrm{Cu}^{\mathrm{II}}$ complex as the $\mathrm{O}-\mathrm{O}$ bond is heterolytically ruptured; the $\mathrm{Fe}^{\mathrm{III}}$ is further oxidized to an $\mathrm{Fe}^{\mathrm{IV}}$ oxoferryl. In the same reaction sequence the phenol is oxidized to a phenoxyl radical. During the process, proton transfer is thought to occur leading to an hydroperoxo intermediate postulated from DFT calculations. ${ }^{8}$

First indication of the oxoferryl-cupric-phenoxyl radical nature of $\mathbf{2}$ is given by spectrophotometric studies ${ }^{6}$ with growing absorptions at $580-620 \mathrm{~nm}$ as was shown in $\mathrm{CcO}$ for the $\mathrm{P}_{\mathrm{M}}$ state $(610 \mathrm{~nm})$ and the $\mathrm{F}^{\bullet}$ state $(575 \mathrm{~nm}) .{ }^{2 \mathrm{ef}}$ Nanospray and electrospray mass spectrometry analyses ${ }^{3 b}$ indicate the formation of 2 with a peak at $\mathrm{m} / \mathrm{z}=1613.2871$ matching the simulated spectrum of a potassium chloride adduct of compound 2.6 An increase of $2 \mathrm{amu}$ is observed when $\mathbf{1}$ is reacted with isotopic ${ }^{18} \mathrm{O}_{2}$. Evidence for the formation of the oxoferryl nature of $\mathbf{2}$ was also established by an oxygen-atom transfer reaction with 
triphenylphosphine ${ }^{9}$ leading in high yield to triphenylphosphine oxide. ${ }^{6,9}$ Previous studies have shown that such a reaction does not occur with $\boldsymbol{o x y}$-1-like species. ${ }^{3 b}$

The radical nature of $\mathbf{2}$ is evidenced by EPR spectroscopy, which we examined in light of the controversy about the EPR spectrum of the $\mathrm{P}_{\mathrm{M}}$ intermediate. ${ }^{1}$ Early studies performed on the enzyme did not show any EPR-signal for the $\mathrm{Cu}(\mathrm{II})$ in a $\mathrm{P}_{\mathrm{M}^{-} \text {-type oxidized enzyme. }}{ }^{2 \mathrm{a}}$ The unpaired electrons of the tyrosyl radical $(\mathrm{S}=1 / 2)$ and of $\mathrm{Cu}_{\mathrm{B}}(\mathrm{II})\left(\mathrm{S}=\mathrm{I}^{1 / 2}\right)$ are expected to be spincoupled (with possible delocalization of spin density onto the imidazole) resulting in an overall silent EPR spectrum for the $\mathrm{P}_{\mathrm{M}}$ intermediate. But subsequent studies have reported an EPRactive intermediate with a $\mathrm{Cu}$ EPR signal that is distorted by the neighboring oxoferryl paramagnet $(S=1) .{ }^{2 b-e, j}$ Another paper invoked a three-electron oxidized enzyme in a oxoferryl/cupric $\mathrm{P}_{\mathrm{R}}$ intermediate where the phenol is not oxidized, ${ }^{2 j}$ although another study using iodide labeling and protein peptide analysis suggested that a tyrosine radical was formed. ${ }^{2 i}$ Also, a $P_{M}$ intermediate generated artificially by treating the enzyme with hydrogen peroxide revealed partial uncoupling for the $\mathrm{CuB} / \mathrm{Tyr} 244$ system and the presence of a tyrosine radical but the $\mathrm{Cu}$ (II) signal was not assigned to $\mathrm{Cu}_{\mathrm{B}} \cdot{ }^{2 \mathrm{f}-\mathrm{h}}$ In addition, upon photolysis of the oxidized enzyme, a radical signal presumably from Tyr 244 , and a $\mathrm{Cu}(\mathrm{II})$ signal were detected. ${ }^{2 \mathrm{k}}$

The EPR spectrum of our complex $\mathbf{2}$ has features reminiscent of a free-base porphyrin crosslinked imidazole-phenoxyl radical, such as a broad signal with shoulders at 3366G and 3445G. It is significantly different than that of a tyrosyl radical ${ }^{2 f-} \mathrm{h}, \mathrm{j}$ or that of an analogous $\mathrm{CcO}$ model bearing zinc in the porphyrin and $\mathrm{Cu}(\mathrm{II})$ in the distal site. ${ }^{5 \mathrm{~b}}$ Broad features at $2800-3000 \mathrm{G}$ in our spectrum are reminiscent of the one observed by Karlsson or Blair in the enzyme. ${ }^{2 b, c, e}$ The signal of $\mathbf{2}$ was observed upon warming oxy -1 to $-40^{\circ} \mathrm{C}$ and was recorded at an early stage because of the high reactivity of $\mathbf{2}$ as reported earlier on similar species. ${ }^{3 b}$ Low temperature, high power experiments did not reveal a signal underlying the observed one at $\mathrm{g} \sim 2.6$ Our spectroscopic data suggest a paramagnetic $\mathrm{Cu}(\mathrm{II}) /$ cross-linked imidazole-phenoxyl radical/ oxoferryl species as depicted in 2, that might represent a model of the $\mathrm{P}_{\mathrm{M}}$ intermediate. But because of 2's complex spin system, possible contributions from several species, and disagreements in the literature, we regard this interpretation of our EPR spectrum to be very tentative; empirical comparisons with reports of the enzyme are dangerous. In future work we plan to clarify this by studying models that contain diverse pairs of the paramagnetic species.

This single-turnover model study shows that phenol behaves as a $\mathrm{H}^{+} / \mathrm{e}^{-}$donor involved in the $\mathrm{O}-\mathrm{O}$ bond cleavage. It validates a scenario in which the enzyme operates in the mixed valence state, and supports the existence of a Tyr244 radical in the enzyme. ${ }^{10}$ Model 1 is a good mimic of the $\mathrm{CcO}$ active site to lead to a $\mathrm{P}_{\mathrm{M}}$ intermediate. Model $\mathbf{1}$ is also a better structural mimic of the enzyme active site than any other models reported to date $\mathrm{e}^{5 \mathrm{~d}-\mathrm{h}}$ because it contains all three redox centers with the right $\mathrm{Fe} / \mathrm{Cu}$ distance and a proximal imidazole. When the redox state of $\mathbf{1}$ is changed to a mixed valence $\mathrm{Fe}^{\mathrm{II}} / \mathrm{Cu}^{\mathrm{II}}$ species, reaction with $\mathrm{O}_{2}$ does not lead to 2 although Resonance Raman shows that $\mathrm{O}_{2}$ binding still occurs. Moreover other studies with an analogous version of $\mathbf{1}$ immobilized on SAM electrode, have shown that the tyrosine mimic is crucial to severely limit the release of PROS during steady state turnover under a rate limiting electron flux. ${ }^{11}$

\section{Supplementary Material}

Refer to Web version on PubMed Central for supplementary material.

\section{Acknowledgments}

This work was supported by the NIH under grant No. 5R01 GM-17880-35 and DK 31450. RAD is thankful for a Lavoisier Fellowship. We are thankful to Dr Allis Chien (SUMS), Dr Todd Eberspacher ( ${ }^{18} \mathrm{O}_{2}$ setup), Peng Cheng (UV), and Dr Takehiro Ohta for helpful discussions. 


\section{References}

1. Ferguson-Miller S, Babcock GT. Chem. Rev 1996;96:2889. [PubMed: 11848844]

2. (a) Clore GM, Andreasson L-E, Karlsson B, Aasa R, Malmstrom BG. Biochem. J 1980;185:155. [PubMed: 6246875] (b) Karlsson B, Andreasson L-E. Biochim. Biophys. Acta 1981;635:73-80. [PubMed: 6260164] (c) Karlsson B, Aasa R, Vanngard T, Malmstrom BG. FEBS Lett 1981;131:186. (d) Hansson O, Karlsson B, Aasa R, Vanngard T, Malmstrom BG. EMBO J 1982;1:1295. [PubMed: 6327262] (e) Blair DF, Witt SN, Chan SI. J. Am. Chem. Soc 1985;107:7389. (f) Fabian M, Palmer G. Biochemistry 1995;34:13802. [PubMed: 7577973] (g) Proshlyakov DA, Pressler MA, Babcock GT. Proc. Natl. Acad. Sci. USA 1998;95:8020. [PubMed: 9653133] (h) MacMillan F, Kannt A, Behr J, Prisner T, Michel H. Biochemistry 1999;38:9179. [PubMed: 10413492] (i) Proshlyakov DA, Pressler MA, DeMaso C, Leykam JF, DeWitt DL, Babcock GT. Science 2000;290:1588. [PubMed: 11090359] (j) Morgan JE, Verhovsky MI, Palmer G, Wikstrom M. Biochemistry 2001;40:6882. [PubMed: 11389603] (k) Pezeshk A, Torres J, Wilson MT, Symons MCR. J. Inorg. Biochem 2001;83:115. [PubMed: 11237250] (1) Barry BA, Einarsdottir O. J. Phys. Chem. B 2005;109:6972. [PubMed: 16851792]

3. (a) Collman JP, Sunderland CJ, Berg K, Vance MA, Solomon EI. J. Am. Chem. Soc 2003;125:6648. [PubMed: 12769571] (b) Collman JP, Decréau RA, Sunderland CJ. Chem. Comm 2006:3894. [PubMed: 17268662]

4. (a) Iwata S, Ostermeier C, Ludwig B, Michel H. Nature 1995;376:660. [PubMed: 7651515] (b) Yoshikawa S, Shinzawa-Itoh K, Nakashima R, Yaono R, Yamashita E, Inoue N, Yao M, Fei MJ, Libeu CP, Mizushima T, Yamaguchi H, Tomizaki T, Tsukihara T. Science 1998;280:1723. [PubMed: 9624044]

5. (a)The synthesis of $\mathbf{1}$ was carried out by stepwise metallation with iron then copper of the previously described free base porphyrin following reported methods. ${ }^{5 b}{ }^{19} \mathrm{~F} \mathrm{NMR}$ is used to ensure that only one $\mathrm{Cu}$ is introduced by comparing the integration of the proximal $\mathrm{CF}_{3}$-probe and the $\mathrm{PF}_{6}$ counterion. 5b,6 (b) Collman JP, Sunderland CJ, Boulatov R. Inorg. Chem 2002;41:2282. [PubMed: 11952386] (c) Collman JP, Decréau RA, Zhang C. J. Org. Chem 2004;69:3546. [PubMed: 15132568] (d) Liu JG, Naruta Y, Tani F, Chishiro T, Tachi Y. Chem. Comm 2004:120. [PubMed: 14737361] (e) Liu JG, Naruta Y, Tani F. Angew. Chem. Int. Ed 2005;44:1836. (f) Kim E, Kamaraj K, Galliker B, Rubie ND, Moenne-Loccoz P, Kaderli, S Zuberbuhler AD, Karlin KD. Inorg. Chem 2005;44:1238. [PubMed: 15732964] (g) Cappuccio JA, Ayala I, Eliott GI, Szundi I, Lewis J, Konopelski JP, Barry BA, Einarsdottir O. J. Am. Chem. Soc 2002;124:1750. [PubMed: 11853453] (h) Nagano Y, Liu J-G, Naruta Y, Ikoma T, Tero-Kubota S, Kitagawa T. J. Am. Chem. Soc 2006;128:14560. [PubMed: 17090040]

6. See supporting information

7. (a) Tsubaki M, Nagai K, Kitagawa T. Biochemistry 1980;19:379. [PubMed: 7352992] (b) Burke JM, Kincaid JR, Peters S, Gagne RR, Collman JP, Spiro TG. J. Am. Chem. Soc 1978;100:6083. (c) Varotsis C, Woodruff WH, Babcock GT. J. Biol. Chem 1990;265:11131. [PubMed: 2162832]

8. Blomberg MRA, Siegbahn PEM, Babcock GT, Wikström M. J. Am. Chem. Soc 2000;122:12848.

9. Chin DH, La Mar GN, Balch AL. J. Am. Chem. Soc 1980;102:5945.

10. Other origins have been proposed: (a) Weng L, Baker GM. Biochemistry 1991;30:5727. [PubMed: 1645999] (b) Rigby SEJ, Juneman S, Rich P, Heathcote P. Biochemistry 2000;39:592. [PubMed: 10642184] (c) Budiman K, Kannt A, Lyubenova S, Richter O-MH, Ludwig B, Michel H, MacMillan F. Biochemistry 2004;43:11709. [PubMed: 15362855] (d) MacMillan F, Budiman K, Angerer H, Michel H. FEBS Lett 2006;580:1345. [PubMed: 16460733]

11. Collman JP, Devaraj NK, Decréau RA, Yang Y, Yan Y-L, Ebina W, Eberspacher TA, Chidsey CED. Science 2007;315:1565. [PubMed: 17363671] 

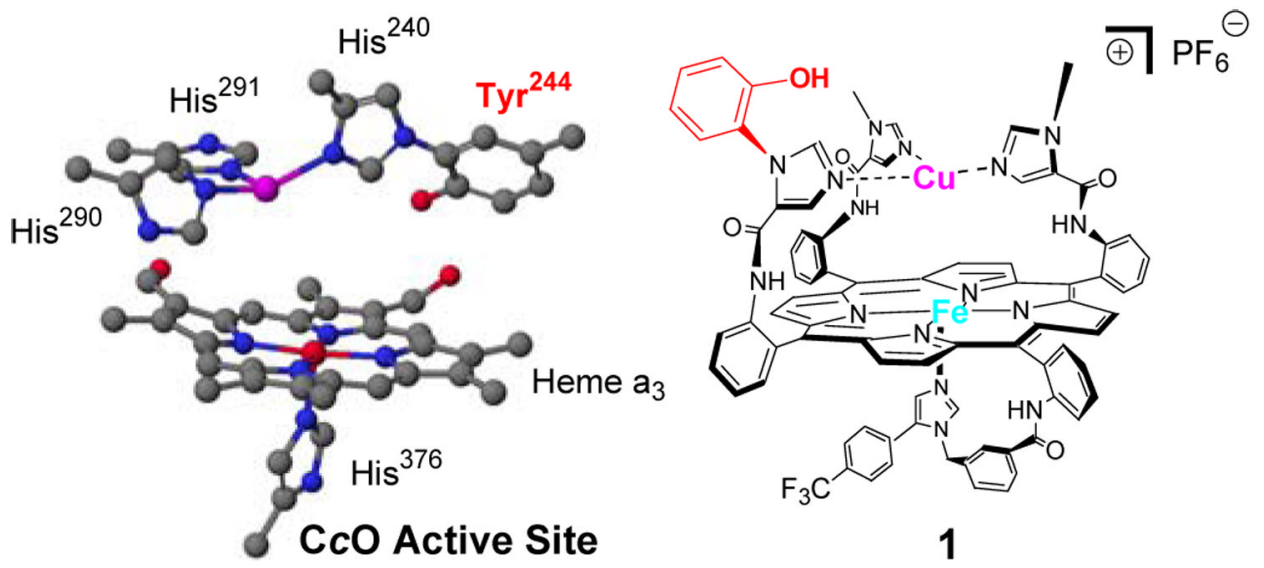

Figure 1.

(Left) Heme $\mathrm{a}_{3} / \mathrm{Cu}_{\mathrm{B}}$ of bovine cytochrome c oxidase. (Right) Chemical Structure of $\mathbf{1}$. 


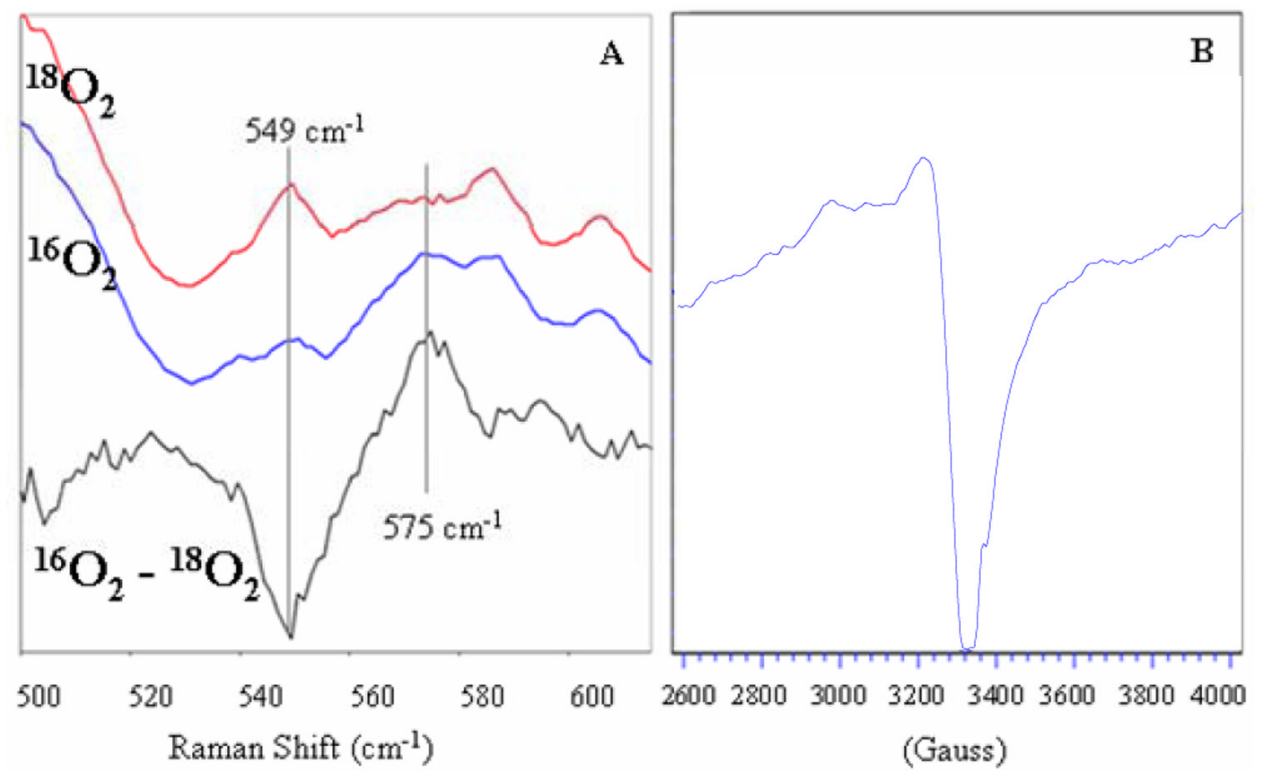

Figure 2.

(A) Evidence of an $\mathrm{Fe}(\mathrm{III})$-superoxo- $\mathrm{Cu}(\mathrm{I})$ species oxy-1 formed by reaction of $\mathbf{1}$ with dioxygen: Resonance Raman (77K, DMF) of $o x y-\mathbf{1 - 1 8} \mathbf{O}_{2}, o x y-\mathbf{1 - 1 6} \mathrm{O}_{\mathbf{2}}$, and the difference spectrum. (B) X-band EPR spectrum (77K in DMF) obtained upon warming up oxy-1 at $-40^{\circ}$ C. 


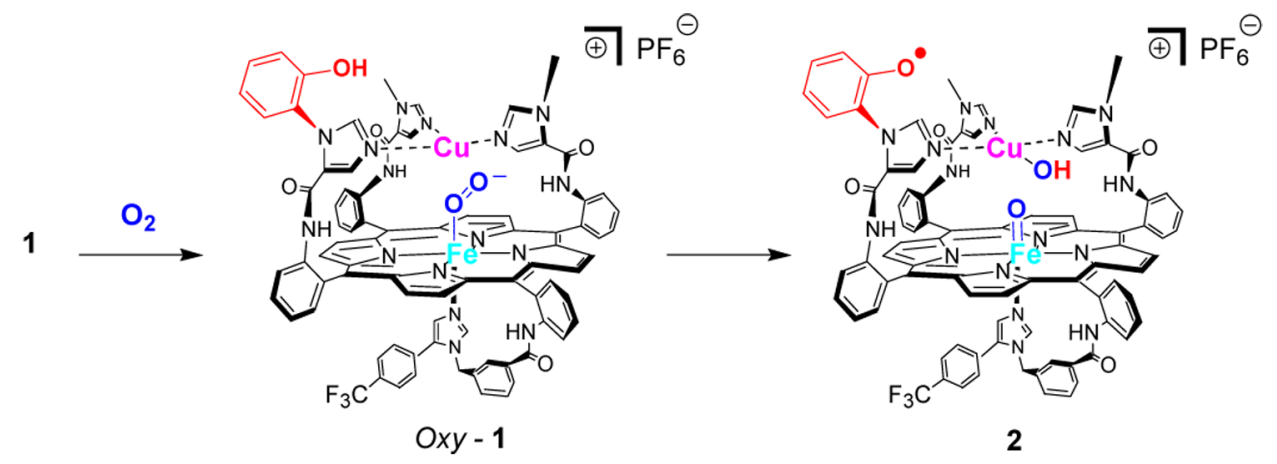

SCHEME 1.

Single turnover intramolecular reaction of 1 with dioxygen leading to $o x y-1$ at $-60^{\circ} \mathrm{C}$, and oxoferryl-cupric-tyrosyl radical mimic species 2 upon warming at $-40^{\circ} \mathrm{C}$. 